\title{
Major contribution of both zooplankton and protists to the top-down regulation of freshwater aerobic anoxygenic phototrophic bacteria
}

\author{
Maria Carolina Garcia-Chaves ${ }^{1, *}$, Matthew T. Cottrell ${ }^{2}$, David L. Kirchman², \\ Alison M. Derry ${ }^{1}$, Matthew J. Bogard ${ }^{1}$, Paul A. del Giorgio ${ }^{1}$

\begin{abstract}
${ }^{1}$ Groupe de recherche interuniversitaire en limnologie, Département des Sciences Biologiques, Université du Québec à Montréal, CP 8888, succursale Centre-Ville, Montréal, QC, H3C 3P8, Canada
\end{abstract} \\ ${ }^{2}$ School of Marine Science and Policy, University of Delaware, 700 Pilottown Rd., Lewes, DE 19958, USA
}

\begin{abstract}
Aerobic anoxygenic phototrophic (AAP) bacteria are photoheterotrophic prokaryotes that use light as a secondary energy source to complement the consumption of organic matter. Despite this metabolic flexibility and their widespread distribution, their low relative abundances suggest that they may be subjected to strong regulatory processes. However, there is still little information on the regulation of AAP abundance, particularly in freshwaters. Here, we used a lake mesocosm experiment to address the top-down regulation of freshwater AAP by protists and zooplankton under 2 contrasting nutrient regimes. Our results support the hypothesis that freshwater AAP are subject to intense top-down regulation, and are selectively removed by grazers. The average gross growth rate of AAP was ca. 1.5 times higher, and grazing loss rates 1.6 times higher than those of the bulk bacterial community. Our results further indicate that whereas protists are the main predators of AAP, zooplankton may account for over a third of AAP losses, and both exhibit a greater selectivity for AAP relative to total bacteria. The mechanistic underpinning of this selectivity is still unclear, but it may be related to the average larger cell size of $\mathrm{AAP}$, and to their higher potential growth rates relative to the bulk bacterial community. Our results further suggest that AAP may play a disproportionate role in the nutrition of lake zooplankton, and in the trophic transfer of organic carbon in lake food webs.
\end{abstract}

KEY WORDS: Aerobic anoxygenic phototrophic bacteria - Grazing loss rate - Selective predation · Photoheterotrophy $\cdot$ Freshwater

Resale or republication not permitted without written consent of the publisher

\section{INTRODUCTION}

Aerobic anoxygenic phototrophic bacteria differ from their heterotrophic counterparts in their potential capacity to use light to supplement their heterotrophic diet of dissolved organic matter. This photoheterotrophic group of bacteria relies on heterotrophy for over $80 \%$ of their cellular energetic demands but can produce a photosynthetic apparatus that captures available energy from light-induced proton translocation (Kolber et al. 2001, Koblízek et al. 2003, Yurkov \& Csotonyi 2009, Koblížek 2015). This metabolic flexibility, together with the cosmopolitan nature of AAP, suggests that the light harvesting capacity may provide these bacteria with a significant ecological advantage, and this group has been hypothesized to play a significant role in the flux of carbon and energy in aquatic systems (Karl 2002, Fenchel 2008, Gasol et al. 2008).

Interestingly, AAP bacteria seldom represent more than $10 \%$ of the prokaryotic community across different types of aquatic ecosystems (Hojerová et al. 2011, 
Lamy et al. 2011, Mašín et al. 2012, Fauteux et al. 2015). Two possible hypotheses may explain their low in situ abundances: either light-derived energy has little effect on the growth and competitiveness of $\mathrm{AAP}$, or, if there is an effect, there are other factors, unrelated to phototrophy, that may limit the ecological success of AAP bacteria more than that of other bacterial groups. Experimental evidence from marine environments suggests that AAP bacteria may have higher growth rates than the average bacteria (Koblízek et al. 2007, Ferrera et al. 2011, Kirchman et al. 2014, Stegman et al. 2014), and therefore their generally low abundance should be due to high losses, either via grazing or viral infection. Indeed, the only study so far to have explored the different controls of the abundance of this group showed that protist grazing was the main regulator of the abundance of marine AAP bacteria (Ferrera et al. 2011). Beyond this marine study, however, there is still little information on the regulation of AAP abundance and activity, especially for inland waters, despite the fact that these photoheterotrophic microbes have also been shown to be widespread in freshwater planktonic food webs (Mašín et al. 2008, Medová et al. 2011, Mašín et al. 2012, Cuperová et al. 2013, Fauteux et al. 2015).

One of the major differences between freshwater and marine planktonic trophic webs is that, whereas in the latter the major grazers of bacteria are protozoans (i.e. ciliates and flagellates), in inland waters there are certain crustacean groups that may also act as potential bacterivores (Güde 1988, Jürgens et al. 1994, Bertilsson et al. 2003). In particular, some cladoceran groups have a filtering apparatus capable of effectively retaining a wide particle size spectrum, including bacteria, cyanobacteria, planktonic protists, and algae, and several field studies have shown a strong predatory control by this group on heterotrophic bacterioplankton in inland waters (Pace et al. 1990, Brendelberger 1991, Jürgens et al. 1994, Kim et al. 2000, Langenheder \& Jürgens 2001, Degans \& Zöllner 2002, Berga et al. 2015). The ability of cladocera to feed on bacteria differs among species and size classes within species, as a function of the size of their filtering apparatus, but larger bacterial cells in general have a higher probability of being retained (Brendelberger 1991, Jürgens 1994). Since AAP bacteria have been shown to be systematically larger than the average bacterioplankton cells (Sieracki et al. 2006, Kirchman et al. 2014, Stegman et al. 2014, Fauteux et al. 2015), this group may be more vulnerable to zooplankton grazing. As a consequence, freshwater AAP bacteria may be grazed by a wider variety of predators than in marine communities, resulting in an even stronger top-down regulation than in marine environments. In turn, these different consumption pathways have implications for the potential trophic role of AAP bacteria at the ecosystem level. If AAP bacteria are grazed mainly by protists, then relatively little of their production will reach higher trophic levels, whereas predation by metazooplankton will greatly increase the potential transfer of AAP production to higher trophic levels.

Here, we explore for the first time the relative contribution of zooplankton and protists in regulating the abundance of freshwater AAP bacteria. We carried out a lake mesocosm experiment specifically aimed at quantifying the grazing of AAP by zooplankton and protists. We further assessed whether AAP bacteria are selectively grazed relative to the bulk bacterial community, and how this biological regulation varies under different nutrient regimes, since prey selectivity may in turn be affected by nutrient availability (Simek et al. 2003, Jezbera et al. 2006). Our results show that freshwater AAP bacteria are indeed more intensely grazed than the bulk bacterial community, and suggest a significant role of cladocerans in selectively controlling the abundance of these ubiquitous photoheterotrophs.

\section{MATERIALS AND METHODS}

\section{Study site and experimental design}

The experiment was carried out in the oligo-mesotrophic Lake Cromwell, located in the temperate region of Québec, Canada ( $45^{\circ} 59^{\prime}$ N 73⒌ $\left.9^{\prime} \mathrm{W}\right)$ at the Station de Biologie des Laurentides, a field research facility of the Université de Montréal (www.sbl. umontreal.ca/index.html). The experiment consisted of 2 parts: (1) a field mesocosm experiment in which zooplankton was manipulated, and (2) a complementary predator-free laboratory re-growth incubation experiment that was carried out on samples taken from the experimental mesocosms. From this approach, we generated 4 basic scenarios: (1) a protist only treatment, corresponding to Phase I of the mesocosm experiment; (2) a protist + zooplankton treatment, corresponding to Phase II of the mesocosm experiment; (3) absence of protists and zooplankton, corresponding to in vitro re-growth experiments using mesocosm samples; and (4) an unmanipulated protist + zooplankton control, corresponding to the ambient lake waters.

In order to assess the effect of zooplankton, and to compare the effect of top-down control on AAP and the bulk bacterial community, the mesocosm experi- 
ment involved enclosures where zooplankton were initially removed and subsequently added. We used 6 polyethylene mesocosms (1 m diameter, $6 \mathrm{~m}$ deep, $4700 \mathrm{l}$, closed bottom), anchored at the bottom, and attached to floating wooden frames in the middle of the lake ( 8 $\mathrm{m}$ depth). Enclosures were filled by pumping surface water sequentially across 2 mesh screens of 110 and $54 \mu \mathrm{m}$ to remove zooplankton. In order to investigate the variation of the top-down regulation under different nutrient regimes, 3 of the mesocosms each received nitrogen $(\mathrm{N})$ and phosphorous $(\mathrm{P})$ additions (nutrient-amended mesocosms); the other 3 mesocosms retained the original lake conditions (unamended mesocosms). In nutrient-amended mesocosms, $\mathrm{KH}_{2} \mathrm{PO}_{4}$ and $\mathrm{NaNO}_{3}$ were added to increase $5 \times$ and $2 \times$, respectively, the ambient lake nutrient concentrations, to values of $50 \mu \mathrm{g} \mathrm{P}$ and $700 \mu \mathrm{g} \mathrm{N} \mathrm{l}{ }^{-1}$.

The initial zooplankton-free phase was run for $6 \mathrm{~d}$ in order to quantify the response of AAP and bulk bacteria to exposure to protist grazing only. At Day 7 of the experiment, the 6 mesocosms were restocked with zooplankton at ambient lake concentrations, collected in the surrounding lake waters using a $54 \mu \mathrm{m}$ Nitex net of $30 \mathrm{~cm}$ diameter and $1 \mathrm{~m}$ in length. This second experimental phase with zooplankton was run for 2 additional weeks. The development of the AAP bacteria and of the bulk community in the mesocosms was followed weekly over the course of $20 \mathrm{~d}$, from 5 to 25 June 2012. Additionally, we measured zooplankton biomass and protists (heterotrophic nanoflagellates) abundances at those same time points.

\section{Response parameters - sampling and analysis}

Total phosphorus (TP), total nitrogen (TN), dissolved organic carbon (DOC), dissolved oxygen (DO), $\mathrm{pH}$, conductivity (Cond) and temperature were measured weekly at $0.5 \mathrm{~m}$ depth in all bags. Entire water column profiles were taken from 1 enclosure per treatment, 2 times during the experiment (Days 1 and 12) using a YSI combination probe to assess the level of water column oxygenation. Photosyntetically active radiation (PAR) profiles were measured using a LI-COR LI-190 Quantum Sensor. In the lab, TP was quantified spectrophotometrically by the molybdenum-blue method following persulfate digestion. TN analysis was conducted as $\mathrm{NO}_{3}{ }^{-}$following alkaline persulfate digestion (Wetzel \& Likens 1979). DOC was measured in $0.45 \mu \mathrm{m}$-filtered samples by wet oxidation using an O.I. Analytical Total Carbon Analyzer.

Chlorophyll a (Chl a) samples were filtered through GF/F filters, frozen and subsequently extracted with hot ethanol. Pigments were measured spectrophotometrically at 750 and $665 \mathrm{~nm}$ using a UV/Vis UltroSpec 2100 spectrophotometer. Bacteriochlorophyll a (BChl a) concentrations were measured on an FL3500-FT fluorometer (Photon Systems Instruments), using the standard calibration curve provided by the manufacturer. Samples were first treated with 3-(3,4-dichlorophenyl)-1,1-dimethylurea (DCMU, $50 \mu \mathrm{M}$ final concentration), an inhibitor of photosystem II in oxygenic phototrophs, so that $\mathrm{BChl}$ a fluorescence could be distinguished from Chl a fluorescence (Koblízek et al. 2005).

Samples for the microscopic enumeration of total bacterial and AAP cells were fixed immediately after collection with $1 \%$ glutaraldehyde (final concentration) and kept refrigerated in the dark until filtration. In the lab, samples were filtered onto $0.2 \mu \mathrm{m}$ poresize black polycarbonate filters and immediately stored at $-80^{\circ} \mathrm{C}$. Total bacteria and AAP abundance and cell size were determined by infrared epifluorescence microscopy, as described by Cottrell et al. (2006). In brief, a section of the black polycarbonate

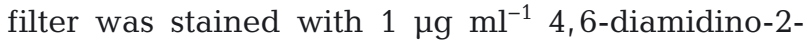
phenylindole (DAPI) for 5 min and then mounted on a microscope slide. AAP and total bacteria were counted using an Olympus Provis AX70 microscope, fitted with a charge-coupled-device camera capable of infrared detection (Intensified Retiga Extended Blue; Qimaging), and image analysis software (ImagePro Plus, Media Cybernetics). To enumerate total bacteria (DAPI-stained) and to discriminate and count AAP bacteria, 20 fields of view were assessed per slide, and 4 images were recorded for each field of view, each at a different excitation and emission wavelength. AAP bacteria, which fluoresce in the infrared (IR), were distinguished from cells containing $\mathrm{Chl} a$ and phycoerythrin-containing cells (PE), which fluoresce in the orange and red, respectively. In addition to abundance, cell size was also determined by image analysis from the DAPI-stained cells using the integration method (Sieracki et al. 1989).

To evaluate the changes in the rate of bacterial biomass production along the course of the experiment, 3 replicates of $1.5 \mathrm{ml}$ of each mesocosm treatment plus 1 trichloroacetic acid-killed control were inoculated with ${ }^{3} \mathrm{H}$-leucine at a final concentration of $20 \mathrm{nM}$ and incubated for $2 \mathrm{~h}$ in the dark and at $20 \pm$ $2{ }^{\circ} \mathrm{C}$. Incubations were terminated by the addition of trichloroacetic acid and the samples were stored at $4^{\circ} \mathrm{C}$ until centrifugation Smith \& Azam (1992).

Zooplankton samples were collected by taking one vertical haul from $5 \mathrm{~m}$ depth to the surface with a $15 \mathrm{~cm}$ diameter $54 \mu \mathrm{m}$ mesh net $(4.5 \%$ of enclosure 
volume). Zooplankton were anaesthetized via carbon dioxide exposure, and preserved in a buffered $4 \%$ sugar-formalin solution for later enumeration. Crustacean zooplankton were identified and population abundances were counted using a high-resolution dissecting microscope (SZ2-IL-ST, Olympus SZ). Taxonomic keys used included Thorp \& Covich (2010) and Witty (2004) for general identification, and Smith \& Fernando (1978) for copepod identification. The taxonomic key of De Melo \& Hebert (1994) was used for the Bosminidae identification, and Haney et al. (2013) as a general visual key. Crustacean zooplankton were enumerated with a protocol design to target mature individuals that would be unambiguously identified to species, as well as to detect rare species (Girard \& Reid 1990). Subsamples $(10 \mathrm{ml})$ were taken from a standardized $50 \mathrm{ml}$ sample volume, and at least 250 individuals were counted so that no more than 50 copepodids per taxonomic Order and no more than 30 nauplii per Order were included in the sum to 250 individuals, even though more were enumerated (Derry \& Arnott 2007).

The abundance of heterotrophic nanoflagellates (HNF) was determined from fixed samples ( $1 \%$ glutaraldehyde, final concentration) by epifluorescence microscopy. Subsamples of $10 \mathrm{ml}$ were stained for 20 min with $200 \mu \mathrm{l}$ of DAPI ( $2 \mu \mathrm{g} \mathrm{ml}^{-1}$ final concentration) and filtered onto $0.8 \mu \mathrm{m}$ black polycarbonate filters. At least 50 flagellates were enumerated on each filter by counting on randomly selected fields.

\section{Estimation of total and AAP bacterial gross growth rates}

In this paper, we refer to bacterial 'net growth rates' as the changes in abundance in the presence of grazers (protists, zooplankton or both), and to 'gross growth rates' as those observed in the absence of grazers. In order to estimate the gross growth rates $\left(\mu_{\mathrm{G}}\right)$ of both total and AAP bacteria, we carried out a re-growth incubation experiment where we released bacteria from grazing. For that purpose, during Day 19 of the experiment, we collected water from the mesocosms and removed both types of grazers (i.e. protists and zooplankton) by filtration through GF/C filters (1.2 $\mu \mathrm{m}$ nominal size). The filtered mesocosm water was then distributed into 2.41 Nalgene transparent bottles and incubated in triplicate in a tank with circulating water held at in situ temperature. The incubation was performed under artificial lighting provided by 24 fluorescent Sun Blaster ${ }^{\mathrm{TM}}$ tubes under $16 \mathrm{~h}$ light and $8 \mathrm{~h}$ dark cycles; incident PAR averaged $200 \mu \mathrm{mol}$ photons $\mathrm{m}^{-2} \mathrm{~s}^{-1}$. The re-growth experiment was run for $3 \mathrm{~d}$ and samples for AAP and total bacterial abundance were taken every $12 \mathrm{~h}$. Total and AAP bacterial gross growth rates were determined from the changes in the number of cells over the incubation time in the re-growth experiment, as the slope of the regression of the natural logarithm (ln) of $\mathrm{N}$ vs time in the filtered sample, where $\mathrm{N}$ is the cell abundance.

\section{Calculation of grazing loss rates of bulk bacteria and AAP bacteria}

In addition to measuring bacterial gross growth rates in the absence of grazing, we measured total and AAP bacterial net growth rates under the 2 experimental conditions: absence or presence of zooplankton in the mesocosms. These net growth rates were estimated as the slope of the regression of $\ln (\mathrm{N})$ vs time, where $\mathrm{N}$ is the cell abundance at the different phases of the mesocosm experiment. Grazing loss rates due to protists $\left(\mathrm{G}_{\mathrm{P}}\right)$ were estimated by the difference between the gross growth rates $\left(\mu_{\mathrm{G}}\right)$ obtained in the re-growth experiment described above, and the net growth rates observed during the initial experimental phase without zooplankton $\left(\mu_{\mathrm{N} 1}\right.$, Days 0 to 6):

$$
\mathrm{G}_{\mathrm{p}}=\mu_{\mathrm{G}}-\mu_{\mathrm{N} 1}
$$

Similarly, the grazing loss rates due to protists and zooplankton $\left(\mathrm{G}_{\mathrm{T}}\right)$ were estimated as the difference between the gross growth rates and the net growth rates observed during the second experimental phase $\left(\mu_{\mathrm{N} 2}\right.$, Days 6 to 12$)$, when both protists and zooplankton were present in the enclosures:

$$
\mathrm{G}_{\mathrm{T}}=\mu_{\mathrm{G}}-\mu_{\mathrm{N} 2}
$$

Grazing loss rates by zooplankton $\left(\mathrm{G}_{\mathrm{Z}}\right)$ were then calculated as the difference between total grazing loss rates and grazing loss rates due to protists:

$$
\mathrm{G}_{\mathrm{Z}}=\mathrm{G}_{\mathrm{T}}-\mathrm{G}_{\mathrm{P}}
$$

\section{RESULTS}

\section{Mesocosm dynamics}

The experimental mesocosms were deployed in Lake Cromwell, which is a typical temperate, oligomesotrophic shield lake $\left(7.9 \mu \mathrm{g} \mathrm{P} \mathrm{l}^{-1}\right)$, with relatively 
low algal biomass (average $2 \mu \mathrm{g} \mathrm{Chl} \mathrm{a} \mathrm{l}^{-1}$ ), moderate water transparency (light extinction coefficient of $1 \mathrm{~m}^{-1}$ ), and an average DOC concentration of $6.4 \mathrm{mg}$ $\mathrm{l}^{-1}$ (Table 1). At the start of the experiment in early June 2012, the lake was thermally stratified $(3.7 \mathrm{~m}$ thermocline depth), with an epilimnetic oxygen concentration of $8.3 \mathrm{mg} \mathrm{l}^{-1}$ and an oxic hypolymnion (6.4 $\mathrm{mg} \mathrm{l}^{-1}$ ) (Table 1). Total and AAP bacterial abundance in the epilimnion was $2.2 \times 10^{6}$ and $1.3 \times$ $10^{4}$ cell ml ${ }^{-1}$, respectively (Table A1 in the Appendix). The zooplankton community of lake Cromwell was dominated by 3 major crustacean zooplankton groups (calanoid and cyclopoid copepods, and cladocerans). Cladocerans were the most abundant group (1.43 ind. $\mathrm{l}^{-1}$ ), composed of the species Sinobosmina liederi, Daphnia ambigua, Daphnia longiremis, and Holopedium spp. Cyclopod copepods were less abundant $\left(0.93\right.$ ind. $\mathrm{l}^{-1}$ ) and were dominated by Cyclops scutifer and Acanthocyclops robustus. Calanoid copepods were the least abundant $\left(0.46\right.$ ind. $\left.1^{-1}\right)$, with Leptodiaptomus minutus as the only representative species. The abundance of heterotrophic nanoflagellates (HNF) ranged from 1-2 $\times 10^{3} \mathrm{ml}^{-1}$ across all treatments, and was on average higher in the nutrient-amended mesocosms (Table A1). The ambient lake density of HNF was relatively stable at around $1.9 \times 10^{3} \mathrm{ml}^{-1}$.

Nutrient enrichment triggered a rapid bacterial response: the initial sample was taken $36 \mathrm{~h}$ after the actual nutrient addition, and by that time total bacterial abundance and production were already 2 -fold higher in the nutrient-amended than in the un- amended mesocosms (Table A1, Fig. 1A). AAP bacterial abundance and $\mathrm{BChl}$ a concentration were also on average higher in the nutrient-amended relative to the un-amended mesocosms (Fig. 1A,B,C). Furthermore, cell size of total and AAP bacterial cells at the beginning of the experiment were both larger (1.5-fold on average) in the nutrient-amended compared with the un-amended mesocosm, and this difference in cell size persisted throughout the entire $3 \mathrm{wk}$ of the experiment (Table A1).

The removal of zooplankton in the first phase of the experiment resulted in a 2- to 3-fold increase in total bacterial abundance (Fig. 1A), and a 27- to 34-fold increase in AAP abundance (Fig. 1A) across the un-amended and the nutrient-amended mesocosms, relative to the initial experimental conditions (Table A1). Since AAP abundance increased more than that of total bacteria, the relative proportion of AAP increased from less than $1 \%$ up to $9 \%$ during the first phase of the experiment in both the unamended and the nutrient-amended mesocosm (Fig. 1B). The reintroduction of zooplankton into the enclosures at the second phase of the experiment, at comparable densities to those in the ambient lake waters, resulted in a strong decline in both total and AAP bacteria, followed by a stabilization after week 2 (Fig. 1A,B). Chl a followed the same pattern as bacteria in response to zooplankton, with an increase in the first phase, and a decline in the second (Fig. 1D), although the changes were much smaller than those observed for bacteria. The removal of zooplankton in Phase II resulted in a slight decrease in HNF abundance in the nutrient amended enclosures (Table A1).

Table 1. Summary of the parameters measured in the mesocosms and Lake Cromwell, Québec, Canada, during the experiment in June and July 2012. Nut-amended: nutrient-amended mesocosm; un-amended: un-amended mesocosm; K: light attenuation coefficient; DO: dissolved oxygen; DOC: dissolved organic matter; Chl a: chloro-

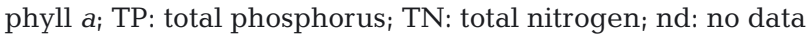

\begin{tabular}{|llcccccccc|}
\hline \multirow{2}{*}{ Day } & Treatment & $\begin{array}{c}\mathrm{K} \\
\left(\mathrm{m}^{-1}\right)\end{array}$ & $\begin{array}{c}\text { Temp. } \\
\left({ }^{\circ} \mathrm{C}\right)\end{array}$ & $\begin{array}{c}\mathrm{DO} \\
\left(\mathrm{mg} \mathrm{l}^{-1}\right)\end{array}$ & $\mathrm{pH}$ & $\begin{array}{c}\text { DOC } \\
\left(\mathrm{mg} \mathrm{l}^{-1}\right)\end{array}$ & $\begin{array}{c}\mathrm{Chl} \mathrm{a} \\
\left(\mu \mathrm{l}^{-1}\right)\end{array}$ & $\begin{array}{c}\mathrm{TP} \\
\left(\mu \mathrm{l}^{-1}\right)\end{array}$ & $\begin{array}{c}\mathrm{TN} \\
\left(\mathrm{mg} \mathrm{l}^{-1}\right)\end{array}$ \\
\hline $\mathbf{1}$ & Nut-amended & nd & 18.7 & nd & 7.1 & nd & nd & 72.2 & nd \\
& Un-amended & nd & 18.7 & nd & 7.4 & nd & 1.63 & 12.37 & nd \\
& Lake & 1.05 & 18.7 & nd & 6.8 & 6.4 & 1.55 & 10.68 & 0.23 \\
$\mathbf{6}$ & Nut-amended & 1.92 & 21.3 & 9.6 & 8.2 & 6.1 & 15.57 & 72.77 & 0.67 \\
& Un-amended & 0.88 & 21.1 & 8.4 & 6.8 & 5.9 & 6.34 & 17.25 & 0.29 \\
& Lake & nd & 21.4 & 8.26 & nd & 5.7 & 2.06 & 9.57 & nd \\
$\mathbf{1 2}$ & Nut-amended & 1.13 & 23.1 & 10.6 & 9.6 & 5.9 & 10.51 & 35.58 & 0.44 \\
& Un-amended & 1.05 & 23.1 & 8.2 & 7.1 & 5.6 & 2.24 & 9.69 & 0.24 \\
& Lake & nd & nd & nd & nd & nd & 2.06 & 9.99 & 0.36 \\
$\mathbf{2 0}$ & Nut-amended & nd & 23.4 & 8.2 & 9.6 & 8.1 & 6.79 & 22.34 & 0.34 \\
& Un-amended & nd & 23.5 & 7 & 7.4 & 7.7 & 1.23 & 7.83 & 0.24 \\
& Lake & nd & 23.1 & 6.59 & nd & 7.4 & 1.29 & 8.38 & 0.27 \\
\hline
\end{tabular}

\section{Bacterial gross and net growth rates}

Gross bacterial growth rates, determined in the grazer-free regrowth experiments, averaged 1.48 $\pm 0.07( \pm \mathrm{SE}$, here and elsewhere $)$ and $1.62 \pm 0.01 \mathrm{~d}^{-1}$ for the bulk bacteria in the nutrient-amended and un-amended treatments, respectively, whereas the gross growth rates of AAP bacteria averaged $2.12 \pm 0.02$ and $2.18 \pm 0.25 \mathrm{~d}^{-1}$ in the nutrient-amended and unamended treatments, respectively (Fig. 2). There were no significant differences ( $t$-test, $\mathrm{p}>0.01)$ in 

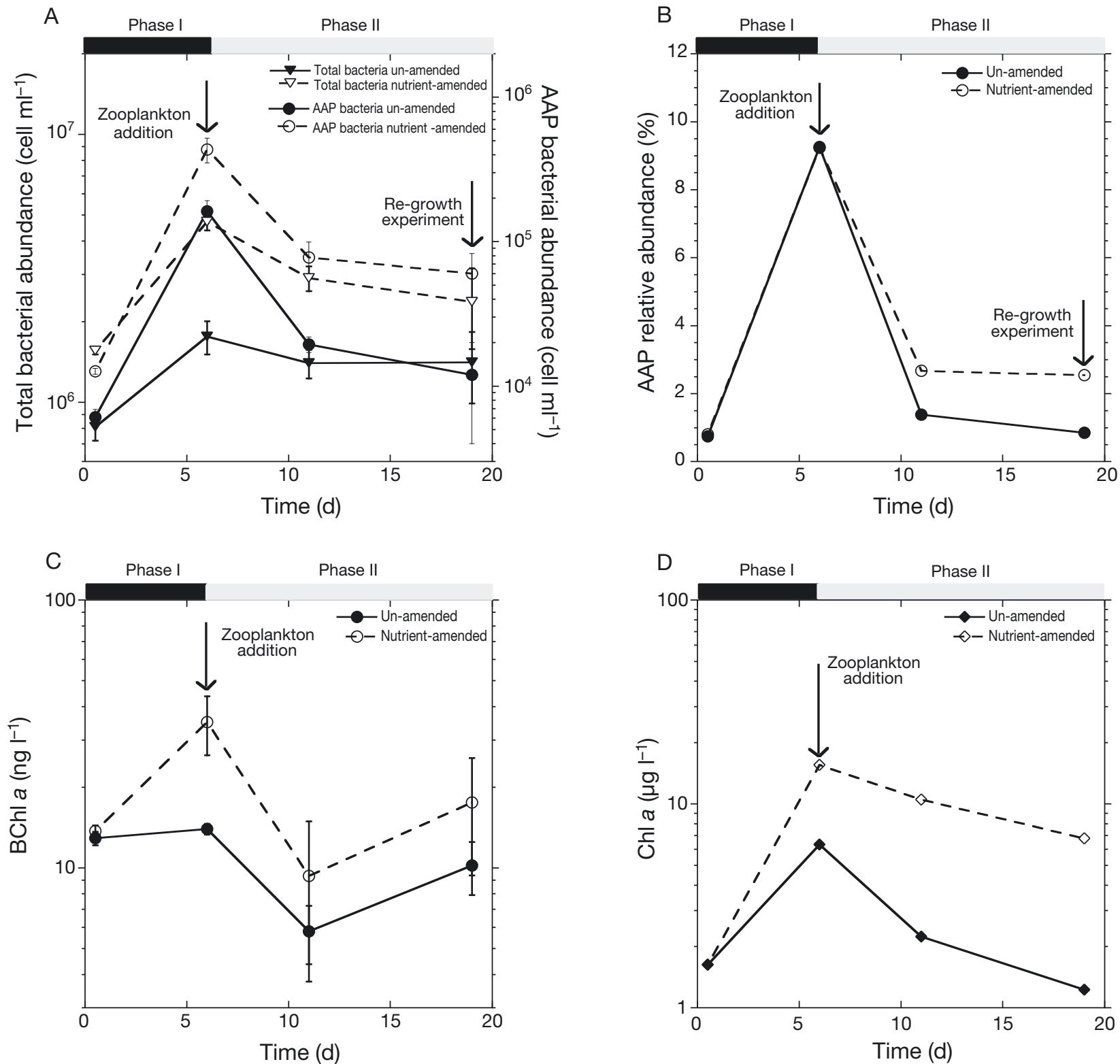

Fig. 1. Dynamics of (A) aerobic anoxygenic phototrophic bacteria (AAP) and total bacterial abundance, (B) relative abundance of AAP bacteria, (C) bacteriochlorophyll a (BChl a) concentration and (D) chlorophyll a concentration (Chl a) throughout the mesocosm experiment. $\log _{10}$ transformed values are presented for (A), (C) and (D). The arrows show the day zooplankton were added into the enclosures and the day of the re-growth experiment. Black and grey horizontal bars correspond to the time periods of the enclosure experiments without zooplankton (Phase I) and with zooplankton (Phase II), respectively. Means $\pm \mathrm{SE}$ are shown

either total bacterial or AAP bacteria gross growth rates between nutrient-amended and un-amended samples, but gross growth rates of AAP bacteria were significantly higher $(t$-test, $p<0.01)$ than those of bulk bacteria in both treatments (Fig. 2).

Total bacterial net growth rates (based on changes in abundance in the mesocosms) in Phase I (absence of zooplankton), averaged $0.18 \pm 0.02$ and $0.13 \pm$
$0.04 \mathrm{~d}^{-1}$ for nutrient-amended and un-amended mesocosms, respectively, and were not significantly different from each other ( $t$-test, $p>0.01)$. Removal of zooplankton in Phase I resulted in even higher net growth rates for AAP bacteria, averaging $0.58 \pm 0.03$ and $0.55 \pm 0.01 \mathrm{~d}^{-1}$ for nutrient-amended and unamended treatments, respectively (Fig. 2). The AAP growth rates under zooplankton-free conditions did 


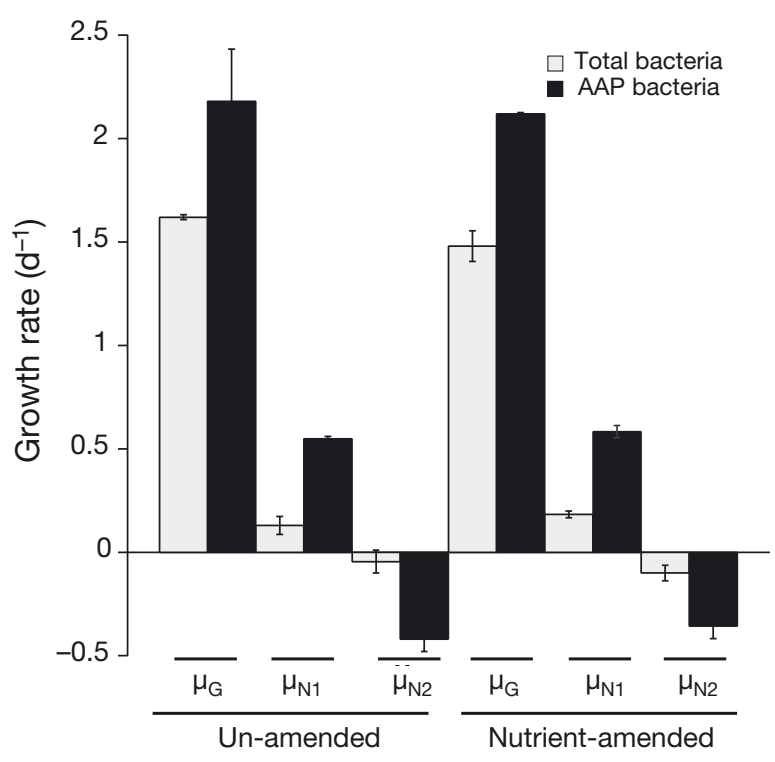

Fig. 2. Growth rates $( \pm \mathrm{SE})$ of total bacteria (grey bars) and aerobic anoxygenic phototrophic (AAP) bacteria (black bars) derived from changes in abundance during the regrowth incubations (gross growth rate, $\mu_{\mathrm{G}}$ ) or during Phase I without zooplankton (net growth rate, $\mu_{\mathrm{N} 1}$ ) or Phase II with zooplankton (net growth rate, $\mu_{\mathrm{N} 2}$ ) of the mesocosm experiment

not differ between nutrient treatments ( $t$-test, $\mathrm{p}>$ 0.01 ), and were significantly greater than total bacterial net growth rates $(t$-test, $\mathrm{p}<0.01)$. The reintroduction of zooplankton to the mesocosms resulted in negative net growth in Phase II for total bacteria $\left(-0.1 \pm 0.04\right.$ and $\left.-0.05 \pm 0.05 \mathrm{~d}^{-1}\right)$, and even more negative values for AAP bacteria $(-0.36 \pm 0.06$ and $-0.42 \pm 0.06 \mathrm{~d}^{-1}$ ) (Fig. 2). During the entire experimental period, bacterial and AAP abundances in the ambient lake waters were very stable (Table A1), with ambient net growth rates of 0.017 and $0.025 \mathrm{~d}^{-1}$ for total bacteria and AAP, respectively.

\section{Grazing loss rates of total and AAP bacteria}

We estimated the grazing loss rates of total bacteria and of AAP from the difference between the gross and net growth rates in the 2 phases of the experiment, using Eqs. (1) \& (2). Grazing loss rates due to protists were on average higher than grazing loss rates due to zooplankton (overall average of 1.48 and $0.60 \mathrm{~d}^{-1}$ by protists and by zooplankton, respectively). Grazing loss rates due to protists ranged from 1.3 to $1.50 \mathrm{~d}^{-1}$ for total bacteria, and from 1.54 to $1.63 \mathrm{~d}^{-1}$ for AAP bacteria (Fig. 3). Grazing loss rates due to zooplankton ranged from 0.17 to $0.28 \mathrm{~d}^{-1}$ for total bacteria, and from 0.94 to $0.97 \mathrm{~d}^{-1}$ for AAP bac-

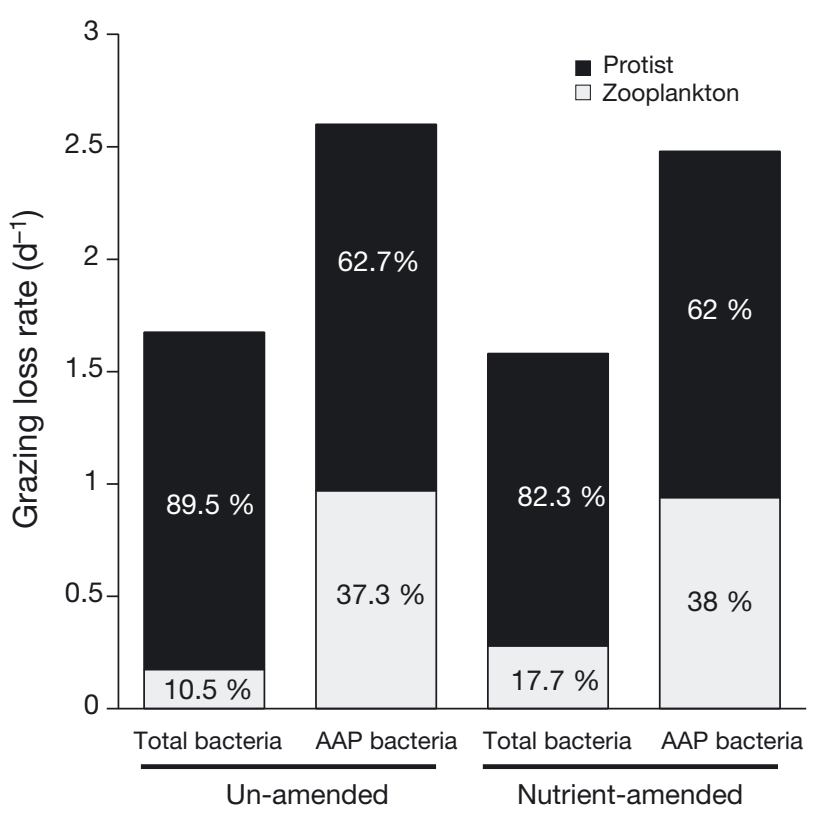

Fig. 3. Mean relative values of protist (black bars) and zooplankton (grey bars) contribution to grazing loss rates of aerobic anoxygenic phototrophic (AAP) and total bacteria in un-amended mesocosms and nutrient-amended mesocosms

teria and accounted for an average of $14 \%$ and $38 \%$ of the overall (protists + zooplankton) grazing loss rates of total bacteria and AAP, respectively (Fig. 3). Grazing loss rates by zooplankton were higher for AAP than for total bacteria (t-test, $\mathrm{p}<0.05)$ (Fig. 3). There was no significant difference in grazing loss rates between nutrient-amended and un-amended mesocosms.

\section{Cell size of AAP bacteria and total bacterial community}

Mean cell size ranged from 0.06 to $0.12 \mu \mathrm{m}^{3}$ for

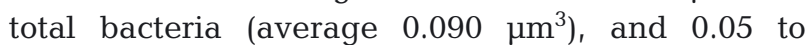
$0.13 \mu^{3}$ (average $0.098 \mu^{3}$ ) for AAP bacteria. AAP cells were on average $10 \%$ larger than total bacterial cells, and this difference increased toward the end of the experiment; overall, there was a significant difference in size between the total and AAP cells (paired $t$-test, $\mathrm{p}<0.005$ ). Nutrient additions resulted in a systematic increase of approx. $25 \%$ in cell size; both for total bacteria and for AAP, and this difference persisted over the course of the experiment and under different grazing regimes (Fig. 4). There was a significant increase in mean cell size, both for the total and the AAP bacteria, upon the reintroduction of zooplankton in Phase II of the experiment (Fig. 4). 


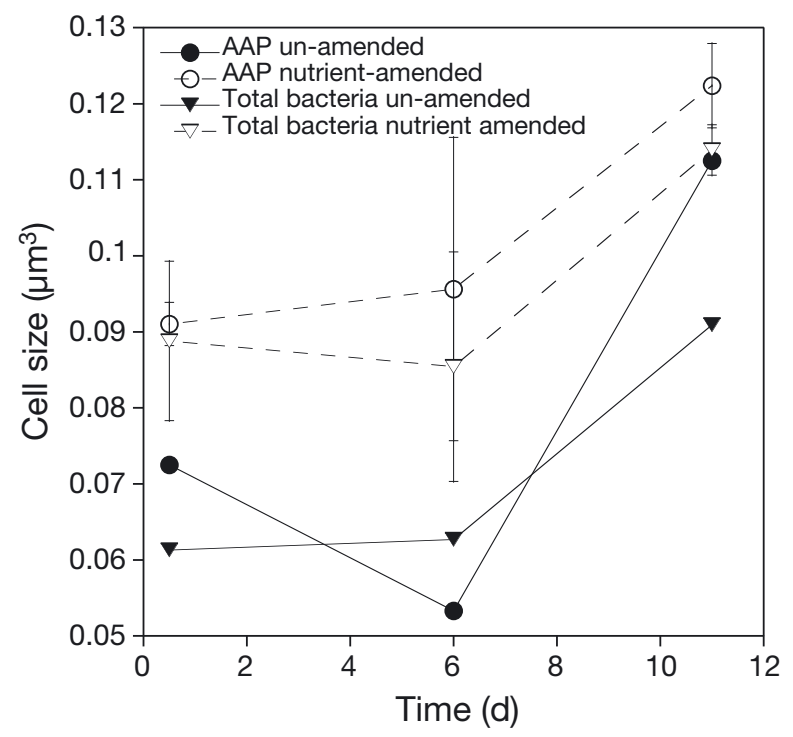

Fig. 4. Changes in mean bacterial cell size through the first $6 \mathrm{~d}$ of the mesocosm experiment when zooplankton were absent (Phase I: Days 1 to 6) and the next $6 \mathrm{~d}$ when zooplankton were present (Phase II: Days 6 to 12)

\section{DISCUSSION}

Much has been learned about the abundance and distribution of AAP bacteria in marine and freshwater systems (Koblízek 2015) since Kolber and coauthors first demonstrated that these bacteria were widely distributed in surface waters throughout the oceans (Kolber et al. 2000). However, information on the regulation of AAP bacteria is still very sparse, and we are far from understanding the ecological role of this group in microbial food webs, and the contribution of AAP bacteria to carbon cycling in aquatic systems. In this paper we have specifically addressed the top-down regulation of AAP bacteria by protists and zooplankton in lakes. We explored whether AAP bacteria are selectively removed relative to the total bacterial community by the main classes of grazers in these systems, and further explored potential interactions between grazing and nutrient availability in shaping AAP dynamics in freshwater systems.

The approach we used was based on following the response of both total bacteria and AAP to the removal of zooplankton and of protists, and deriving from these observations the relative contribution of these 2 predator types to the loss rates of total bacteria and AAP bacteria. While it is possible to remove zooplankton from the mesocosms, it is very difficult to expose these bacterial communities to zooplankton only (without protists). To overcome this limitation, we initially removed zooplankton from our experimental mesocosms in order to subject bacteria only to protist grazing, and subsequently reintroduced zooplankton to the mesocosms and followed the ensuing total bacterial and AAP dynamics. In addition, we carried out re-growth experiments using the mesocosm waters to estimate total bacterial and AAP growth rates in the absence of both protists and zooplankton grazing.

Our results revealed a systematic difference in growth rates of AAP and total bacteria in lake Cromwell; the average gross growth rate of AAP was about 1.5 times higher than that of total bacteria. We acknowledge that these gross growth rates may likely be underestimates, since both total bacteria and AAP were still subjected to some degree of viral infection, although the dilutions likely led to an initial decoupling between bacteria and viruses as well. Regardless of any potential viral or other effects on our estimates, our results are generally consistent with the handful of previous marine studies that have also reported high potential growth rates for AAP relative to the bulk community (Table 2). To our knowledge, similar estimates have not been reported for freshwaters. Ferrera et al. (2011) reported that AAP bacteria grew ca. 2-fold faster than the total bacterial community in the Mediterranean Sea, using a regrowth approach that was very similar to ours. Other studies using different approaches to calculate growth rates of AAP have reported even higher differences in their growth rate relative to total bacteria. Liu et al. (2010) reported a 4-fold higher average AAP growth rate, estimated on the basis of the fre-

Table 2. Summary of growth rates of total bacteria (Total) and aerobic anoxygenic phototrophic bacteria (AAP) from marine and freshwater systems and the corresponding mean relative abundance of AAP. NR: no data reported

\begin{tabular}{|c|c|c|c|c|c|}
\hline \multirow[t]{2}{*}{ System } & \multirow[t]{2}{*}{ Treatment } & \multicolumn{2}{|c|}{ Growth rates $\left(\mathrm{d}^{-1}\right)$} & \multirow{2}{*}{$\begin{array}{c}\text { Mean AAP } \\
\text { abundance (\%) }\end{array}$} & \multirow[t]{2}{*}{ Source } \\
\hline & & Total & AAP & & \\
\hline Lake & Dilution & $1.5-1.6$ & $2.1-2.2$ & $0.6-0.8$ & This study \\
\hline Coastal & Dilution & 1.3 & $2.4-2.6$ & $5-7$ & (Ferrera et al. 2011) \\
\hline Ocean & Untreated & $0.23-0.45$ & $0.5-2.9$ & $2-2.6$ & (Liu et al. 2010) \\
\hline Bay & Untreated & NR & 1.4 & 3.8 & (Hojerová et al. 2011) \\
\hline Ocean & Untreated & NR & 1.1 & 3.1 & (Hojerová et al. 2011) \\
\hline Ocean & Untreated & NR & $0.7-0.9$ & $2-4$ & (Koblízek et al. 2007) \\
\hline Ocean & Untreated & NR & $1.3-1.7$ & NR & (Koblízek et al. 2007) \\
\hline Ocean & Untreated & NR & $1.4-2.1$ & NR & (Koblízek et al. 2007) \\
\hline Ocean & Untreated & NR & $1.4-2.2$ & $3-10$ & (Koblízek et al. 2005) \\
\hline
\end{tabular}


quency of dividing cells. Koblízek et al. (2007), on the other hand, reported AAP growth rates in the Atlantic ocean, based on the diurnal decay in BChl $a$, that were on average 10-fold higher than the average bulk bacterial growth rates that have been measured at those sites (Ducklow 2000). Clearly, AAP bacteria appear to grow faster than the bulk bacterial community across a diverse range in aquatic habitats, although methodological differences in rate estimates across studies currently prevent us from drawing strong quantitative conclusions about patterns in AAP growth rates.

Although it is unclear why the potential growth rate of AAP bacteria appears to be higher than that of the average bacteria, a basic hypothesis is that lightderived energy has a positive effect on the growth and competitiveness of AAP bacteria (Koblízek et al. 2010, Hauruseu \& Koblížek 2012, Kirchman \& Hanson 2012). Two recent studies have measured the activity of total bacteria and AAP cells by quantifying their incorporation of leucine using microautoradiography (Kirchman et al. 2014, Stegman et al. 2014), and concluded that AAP bacteria were indeed up to 40 to $60 \%$ more active than average cells in the community. Interestingly, light did not enhance AAP cell activity, neither in the experimental incubations of Delaware estuary samples nor in the West Antarctic Peninsula water, so the higher apparent intrinsic growth rates of AAP bacteria may not be directly related to phototrophy. It is clear that there is much still to learn on the regulation of the performance of this group.

The re-growth experiments from which we derived the gross growth rates were carried out during the third week of the experiment. Although such timing is unlikely to have influenced the difference in growth rates between AAP and total bacteria, it could have biased the absolute rates obtained, especially if the mesocosms had diverged greatly over time, rendering the resulting rates less applicable to the initial conditions. Our results suggest, however, that bacterial biomass and production were relatively stable in the mesocosms through time $(<40 \%$ total variability). Moreover, our estimated gross growth rates for the whole bacterial community agree well with those reported for 20 lakes located also in Québec, Canada, which ranged from 0.14 to $1.4 \mathrm{~d}^{-1}$ (Smith \& Prairie 2004). We conclude that the pattern in gross growth rates between treatments and between total and AAP bacteria that we observed in the re-growth experiments is likely applicable to the dynamics that occurred over the first 2 wk of the experiment. There is the possibility, however, that the actual growth rates may have been somewhat higher in the initial weeks, which would result in a slight underestimation of the total grazing rates, but without necessarily biasing the relative contribution of protists and zooplankton that we report here.

The nutrient addition led to increases in $\mathrm{Chl} \mathrm{a}$ relative to the un-amended mesocosms (Fig. 1D, Table 1). There was a rapid increase in bacterial abundances together with a 20 to $30 \%$ increase in the cell volume during the first day following the nutrient enrichment, and this difference remained for the length of the experiment (Figs. 1A \& 4). In spite of this initial deviation in bacterial cell abundance and cell size, the average gross and net growth rates for AAP and total bacteria were similar between amended and un-amended treatments, suggesting that either bacterial growth was not nutrient-limited, or that nutrient-driven initial differences in growth were matched by proportional losses, either from grazing or viral infection.

The higher average potential growth rates of AAP bacteria should result in a significant contribution to total community biomass, and yet AAP bacteria are consistently a small proportion of total bacterial abundance across fresh, estuarine, and marine waters (Mašín et al. 2012, Cuperová et al. 2013, Kirchman et al. 2014, Fauteux et al. 2015, and see additional references in Table 2). This was also the case in Lake Cromwell (this study): we found that AAP bacteria also had high potential growth rates, yet their relative abundance was less than $1 \%$. One hypothesis to explain the low relative abundance of AAP bacteria, in spite of their higher potential growth, is that this group is selectively removed, either by predators or by viruses. In this study, we did not test the potential role of viral lysis on the regulation of AAP bacteria, but our results amply support the hypothesis that this group is selectively grazed. The integrated loss rates of the bulk bacterial community due to the combined protist and zooplankton grazing ranged between 1.6 and $1.7 \mathrm{~d}^{-1}$ (Fig. 3), comparable to those reported in other studies (Yokokawa \& Nagata 2005), whereas the integrated loss rates of AAP bacteria were on average 1.6 times higher $\left(2.5\right.$ to $\left.2.6 \mathrm{~d}^{-1}\right)$. It is clear from these results that AAP bacteria are subjected to very strong top down control in lakes.

It is interesting to note that whereas AAP loss due to protist grazing was only slightly higher than that of total bacteria (1.5-1.6 vs $1.3-1.5 \mathrm{~d}^{-1}$ for AAP bacteria and total bacteria, respectively), AAP loss due to zooplankton was 3 to 6 -fold higher than that of total bacteria. Experimental studies have demonstrated that 
protist grazing is generally size-selective, with protists preferentially grazing on medium to larger-sized planktonic bacterial cells (Gonzalez et al. 1990, Simek \& Chrzanowski 1992, Hahn \& Höfle 2001, Jürgens \& Matz 2002). Grazing of planktonic bacteria by cladocerans has also been shown to be sizeselective, depending on their body size and on the configuration of their filtering apparatus (Jürgens 1994, Bertilsson et al. 2003). In this regard, our results suggest that AAP bacteria are on average larger than the average bacterial cells, a pattern that has been reported before both for marine (Sieracki et al. 2006, Koblízek et al. 2010, Hojerová et al. 2011, Kirchman et al. 2014) and freshwater communities (Cuperová et al. 2013, Fauteux et al. 2015). The differential size distribution of AAP bacteria may thus explain their increased vulnerability to grazing in general, leading to selective removal and low relative abundances. Previous studies have also shown that selective predation may respond not only to cell size but also to cell activity (del Giorgio et al. 1996, Jezbera et al. 2005, del Giorgio \& Gasol 2008, Montagnes et al. 2008). In this regard, our results further suggest that AAP bacteria may have morphological and physiological traits that render the group particularly vulnerable to grazing by cladocerans, which establishes a strong trophic link that goes beyond the microbial food web, and which suggests that AAP bacteria may in fact be disproportionately important for the nutrition of this keystone planktonic group.

Strong size-selective grazing should influence the cell size distribution within bacterial communities, and more particularly, within AAP bacteria, when grazers are experimentally removed or added, but these shifts were not obvious in our experimental phases. There was a very modest decrease in mean cell volume of AAP bacteria exposed to only protist grazing, and the reintroduction of zooplankton actually resulted in an increase of the mean cell size of both AAP and total bacteria, in both amended and un-amended mesocosms (Fig. 4). This increase in bacterial cell size under exposure to both protist and zooplankton grazing is rather counterintuitive in the context of direct grazing, but may be explained as the effect of indirect trophic cascade interactions associated with the presence of zooplankton (likely cladocerans). The size-selective grazing of zooplankton on protists could change the size structure of protists and consequently the cell size distribution of the AAP bacteria and total bacteria. The importance of indirect effects of zooplankton on bacterial communities via trophic cascades has already been emphasized in previous studies (Zöllner et al. 2003,
Brucet et al. 2008, Compte et al. 2009). Interestingly, our results show that mean bacterial and AAP sizes were influenced in a similar way by the experimental shifts in predation, suggesting that this mechanism influenced bacteria as a whole and not specific groups within the community.

Regardless of the underlying mechanisms involved, our experiments provide evidence that freshwater AAP bacteria are subject to intense top-down regulation, and are selectively removed by grazers relative to the bulk bacterial community. Our results further demonstrate that whereas protists are the main predators of AAP bacteria, zooplankton (likely cladocerans) may nevertheless account for over a third of AAP losses, exhibiting a much greater selectivity for AAP bacteria than protists. The mechanistic underpinning of this selectivity is still unclear, but it may be related to the average larger cell size of AAP bacteria, and to the higher potential growth rates of AAP relative to the average bacterial community. This strong preference for AAP bacteria by cladoceran zooplankton establishes a direct trophic link between lake metazoans and the microbial food web, which coupled to the high potential for growth that characterizes AAP bacteria, as demonstrated here, implies that AAP bacteria may play a disproportionate role in the nutrition of lake zooplankton, and in the trophic transfer of organic $\mathrm{C}$ in lake food webs.

Acknowledgements. We thank Anthony Merante, M. Robidoux, K. Bareil-Parenteau, K. Laplante, A. Saint-Pierre, A. Parkes and V. Ouellet Jobin for great field and laboratory assistance, C. Ruiz-González, J.P. Niño and J.F. Lapierre for drawings and stimulating discussions, and to H.S.C for inspiration. The logistical support of SBL field station staff is appreciated. This research was support by grants from the National Science and Engineering Research Council of Canada (NSERC) to P.d.G. and A.D.

\section{LITERATURE CITED}

Berga M, Ostman O, Lindström ES, Langenheder S (2015) Combined effects of zooplankton grazing and dispersal on the diversity and assembly mechanisms of bacterial metacommunities. Environ Microbiol 17:2275-2287

Bertilsson S, Hansson L, Graneli W, Philibert A (2003) Sizeselective predation on pelagic microorganisms in Arctic freshwaters. J Plankton Res 25:621-631

Brendelberger H (1991) Filter mesh size of cladocerans predicts retention efficiency for bacteria. Limnol Oceanogr 36:884-894

Brucet S, Compte J, Boix D, López-Flores R, Quintana XD (2008) Feeding of nauplii, copepodites and adults of Calanipeda aquaedulcis (Calanoida) in Mediterranean salt marshes. Mar Ecol Prog Ser 355:183-191

Compte J, Brucet S, Gascón S, Boix D, Sala J, López-Flores R, Quintana XD (2009) Impact of different developmen- 
tal stages of Daphnia magna (Straus) on the plankton community under different trophic conditions. Hydrobiologia 635:45-56

Cottrell MTM, Mannino A, Kirchman DL (2006) Aerobic anoxygenic phototrophic bacteria in the Mid-Atlantic Bight and the North Pacific Gyre. Appl Environ Microbiol 72:557-564

> Cuperová Z, Holzer E, Salka I, Sommaruga R, Koblízek M (2013) Temporal changes and altitudinal distribution of aerobic anoxygenic phototrophs in mountain lakes. Appl Environ Microbiol 79:6439-6446

> Degans H, Zöllner E (2002) Rapid Daphnia-mediated changes in microbial community structure: an experimental study. FEMS Microbiol Ecol 42:137-149

del Giorgio PA, Gasol JM (2008) Physiological structure and single-cell activity in marine bacterioplankton. In: Kirchman DL (ed) Microbial ecology of the oceans, 2nd edn. John Wiley \& Sons, Hoboken, NJ, p 243-298

del Giorgio PA, Gasol JM, Vaque D, Mura P, Agustí S, Duarte CM (1996) Bacterioplankton community structure: protists control net production and the proportion of active bacteria in a coastal marine community. Limnol Oceanogr 41:1169-1179

Derry AM, Arnott SE (2007) Zooplankton community response to experimental acidification in boreal shield lakes with different ecological histories. Can J Fish Aquat Sci 64:887-898

Ducklow H (2000) Bacterial production and biomass in the oceans. In: Kirchman DL (ed) Microbial ecology of the oceans. Wiley-Liss, New York, NY, p 85-120

> Fauteux L, Cottrell MT, Kirchman DL, Borrego CM, GarciaChaves MC, del Giorgio PA (2015) Patterns in abundance, cell Size and pigment content of aerobic anoxygenic phototrophic bacteria along environmental gradients in northern lakes. PLoS ONE 10:e0124035

> Fenchel T (2008) The microbial loop - 25 years later. J Exp Mar Biol Ecol 366:99-103

> Ferrera I, Gasol JM, Sebastián M, Hojerová E, Koblízek M (2011) Comparison of growth rates of aerobic anoxygenic phototrophic bacteria and other bacterioplankton groups in coastal Mediterranean waters. Appl Environ Microbiol 77:7451-7458

Gasol JM, Pinhassi J, Alonso-Sáez L, Ducklow H and others (2008) Towards a better understanding of microbial carbon flux in the sea. Aquat Microb Ecol 53:21-38

Girard R, Reid RA (1990) Dorset Research Centre study lakes: sampling methodology (1986-1989) and lake morphometry. Data report, Ontario Ministry of the Environment, Toronto

Gonzalez JM, Sherr EB, Sherr BF (1990) Size-selective grazing on bacteria by natural assemblages of estuarine flagellates and ciliates. Appl Environ Microbiol 56:583-589

Güde H (1988) Direct and indirect influences of crustacean zooplankton on bacterioplankton of Lake Constance. Hydrobiologia 159:63-73

> Hahn MW, Höfle MG (2001) Grazing of protozoa and its effect on populations of aquatic bacteria. FEMS Microbiol Ecol 35:113-121

Haney J, Aliberti M, Allan E, Allard S, Bauer JD, Beagen W (2013) An image-based key to the zooplankton of North America. Center for Freshwater Biology, University of New Hampshire, NH

> Hauruseu D, Koblížek M (2012) The influence of light on carbon utilization in aerobic anoxygenic phototrophs. Appl Environ Microbiol 78:7414-7419
Hojerová E, Mašín M, Brunet C, Ferrera I, Gasol JM, Koblížek M (2011) Distribution and growth of aerobic anoxygenic phototrophs in the Mediterranean Sea. Environ Microbiol 13:2717-2725

> Jezbera J, Hornák K, Simek K (2005) Food selection by bacterivorous protists: insight from the analysis of the food vacuole content by means of fluorescence in situ hybridization. FEMS Microbiol Ecol 52:351-363

Jezbera J, Hornák K, Simek K (2006) Prey selectivity of bacterivorous protists in different size fractions of reservoir water amended with nutrients. Environ Microbiol 8: 1330-1339

Jürgens K (1994) Impact of Daphnia on planktonic microbial food webs - a review. Mar Microb Food Webs 8: 295-324

Jürgens K, Matz C (2002) Predation as a shaping force for the phenotypic and genotypic composition of planktonic bacteria. Antonie van Leeuwenhoek 81:413-434

Jürgens K, Gasol J, Massana R, Pedrós-Alio C (1994) Control of heterotrophic bacteria and protozoans by Daphnia pulex in the epilimnion of Lake Ciso. Arch Hydrobiol 131:55-78

> Karl DM (2002) Hidden in a sea of microbes. Nature 415: 590-591

Kim H, Hwang S, Joo G (2000) Zooplankton grazing on bacteria and phytoplankton in a regulated large river (Nakdong River, Korea). J Plankt Res 22:1559-1577

Kirchman DL, Hanson TE (2012) Bioenergetics of photoheterotrophic bacteria in the oceans. Environ Microbiol Rep 5:188-199

Kirchman DL, Stegman MR, Nikrad MP, Cottrell MT (2014) Abundance, size, and activity of aerobic anoxygenic phototrophic bacteria in coastal waters of the West Antarctic Peninsula. Aquat Microb Ecol 73:41-49

Koblížek M (2015) Ecology of aerobic anoxygenic phototrophs in aquatic environments. FEMS Microbiol Rev, doi:10.1093/femsre/fuv032

Koblízek M, Béjà O, Bidigare RR, Christensen S and others (2003) Isolation and characterization of Erythrobacter sp. strains from the upper ocean. Arch Microbiol 180: 327-338

- Koblízek M, Sto -Egiert J, Sagan S, Kolber ZS (2005) Diel changes in bacteriochlorophyll a concentration suggest rapid bacterioplankton cycling in the Baltic Sea. FEMS Microbiol Ecol 51:353-361

Koblízek M, Masín M, Ras J, Poulton AJ, Prásil O (2007) Rapid growth rates of aerobic anoxygenic phototrophs in the ocean. Environ Microbiol 9:2401-2406

Koblízek M, Mlcousková J, Kolber Z, Kopecký J (2010) On the photosynthetic properties of marine bacterium COL2P belonging to Roseobacter clade. Arch Microbiol 192:41-49

Kolber ZS, Van Dover CL, Niederman RA, Falkowski PG (2000) Bacterial photosynthesis in surface waters of the open ocean. Nature 407:177-179

Kolber ZS, Gerald F, Lang A (2001) Contribution of aerobic photoheterotrophic bacteria to the carbon cycle in the ocean. Science 292:2492-2495

Lamy D, Jeanthon C, Cottrell MT, Kirchman DL and others (2011) Ecology of aerobic anoxygenic phototrophic bacteria along an oligotrophic gradient in the Mediterranean Sea. Biogeosciences 8:973-985

Langenheder S, Jürgens K (2001) Regulation of bacterial biomass and community structure by metazoan and protozoan predation. Limnol Oceanogr 46:121-134 
Liu R, Zhang Y, Jiao N (2010) Diel variations in frequency of dividing cells and abundance of aerobic anoxygenic phototrophic bacteria in a coral reef system of the South China Sea. Aquat Microb Ecol 58:303-310

Mašín M, Nedoma J, Pechar L, Koblížek M (2008) Distribution of aerobic anoxygenic phototrophs in temperate freshwater systems. Environ Microbiol 10:1988-1996

Mašín M, Čuperová Z, Hojerová E, Salka I, Grossart HP, Koblížek M (2012) Distribution of aerobic anoxygenic phototrophic bacteria in glacial lakes of northern Europe. Aquat Microb Ecol 66:77-86

Medová H, Boldareva EN, Hrouzek P, Borzenko SV and others (2011) High abundances of aerobic anoxygenic phototrophs in saline steppe lakes. FEMS Microbiol Ecol 76:393-400

Melo DR, Hebert PDN (1994) A taxonomic reevaluation of North American Bosminidae. Can J Zool 72:1808-1825

Montagnes DJS, Barbosa AB, Boenigk J, Davidson K and others (2008) Selective feeding behaviour of key freeliving protists: avenues for continued study. Aquat Microb Ecol 53:83-98

Pace M, McManus G, Findlay S (1990) Planktonic structure determines the fate of bacterial production in a temperate lake. Limnol Oceanogr 35:795-808

Sieracki ME, Viles CL, Webb KL (1989) Algorithm to estimate cell biovolume using image analyzed microscopy. Cytometry 10:551-557

Sieracki M, Gilg I, Thier E, Poulton NJ, Goericke R (2006) Distribution of planktonic aerobic anoxygenic photoheterotrophic bacteria in the northwest Atlantic. Limnol Oceanogr 51:38-46

Šimek K, Chrzanowski TH (1992) Direct and indirect evidence of size-selective grazing on pelagic bacteria by freshwater nanoflagellates. Appl Environ Microbiol 58: 3715-3720

Šimek K, Hornák K, Masín M, Christaki U, Nedoma J, Wein- bauer MG, Dolan JR (2003) Comparing the effects of resource enrichment and grazing on a bacterioplankton community of a meso-eutrophic reservoir. Aquat Microb Ecol 31:123-135

Smith DC, Azam F (1992) A simple, economical method for measuring bacterial protein synthesis rates in seawater using 3H-leucine 1. Mar Biol Res 6:107-114

Smith EM, Prairie YT (2004) Bacterial metabolism and growth efficiency in lakes: the importance of phosphorus availability. Limnol Oceanogr 49:137-147

Smith KE, Fernando C (1978) A guide to the freshwater calanoid and cyclopoid Copepoda. Crustacea of Ontario. Univ Waterloo Biol Ser 18:1-76

Stegman MR, Cottrell MT, Kirchman DL (2014) Leucine incorporation by aerobic anoxygenic phototrophic bacteria in the Delaware estuary. ISME J 8:2339-2348

Thorp AP, Covich J (eds) (2010) Ecology and classification of North American freshwater invertebrates. Elsevier Academic Press, London

Wetzel RG, Likens GE (1979) Limnological analysis. W.B. Saunders Company, New York, NY

Witty LM (2004) Practical guide to identifying freshwater crustacean zooplankton, 2nd edn. Cooperative Freshwater Ecology Unit, Sudbury, ON

> Yokokawa T, Nagata T (2005) Growth and grazing mortality rates of phylogenetic groups of bacterioplankton in coastal marine environments. Appl Environ Microbiol 71:6799-6807

Yurkov V, Csotonyi J (2009) New light on aerobic anoxygenic phototrophs. In: Hunter CN, Daldal F, Thurnauer M, Beatty JT (eds) The purple phototrophic bacteria. Springer, Dordrecht, p 31-55

Zöllner E, Santer B, Boersma M, Hoppe HG, Jürgens K (2003) Cascading predation effects of Daphnia and copepods on microbial food web components. Freshw Biol 48: 2174-2193 


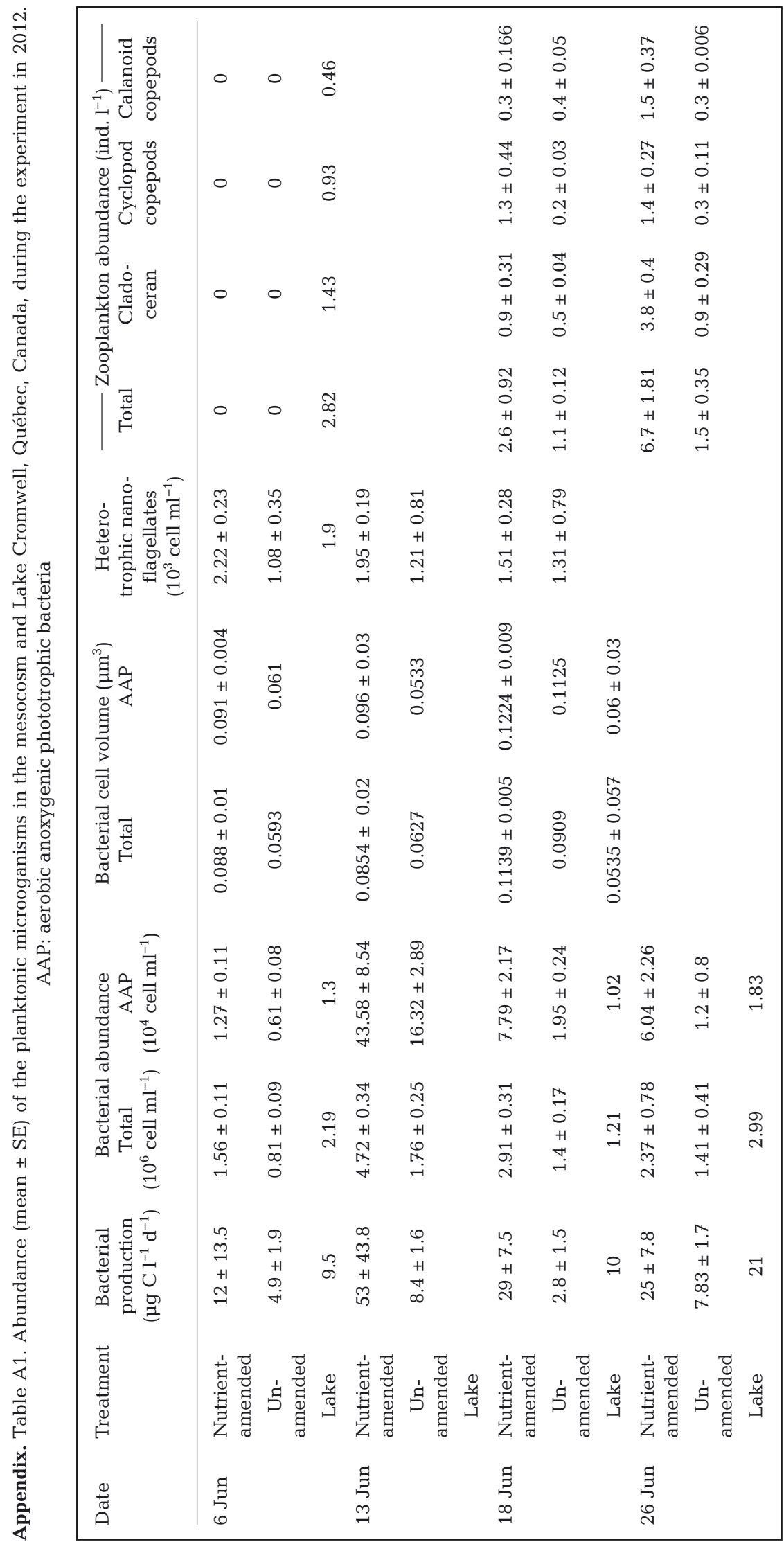

